UDC 378.011.3-051(437.3):376-056.2/.3

DOI: $10.31470 / 2415-3729-2019-9-157-177$

\title{
Czech Experience of Future Teachers Training to Work in the Conditions of Inclusive Education
}

\section{Oksana Pluzhnyk}

Postgraduate student of the Department of Pedagogy

Pereiaslav-Khmelnytskyi Hryhorii Skovoroda State

Pedagogical University,

$\square$ 30, Sukhomlynskyi Str., Pereiaslav-Khmelnytskyi, Kyiv

Region, Ukraine, 08401

E-mail: oks.pluzhnik1@gmail.com

ORCID: 0000-0001-8780-8288

\section{Olha Shapran}

Doctor of Pedagogy, Professor,

Head of the Department of Pedagogy

Pereiaslav-Khmelnytskyi Hryhorii Skovoroda State

Pedagogical University,

$\square$ 30, Sukhomlynskyi Str., Pereiaslav-Khmelnytskyi, Kyiv

Region, Ukraine, 08401

E-mail: olia.shapran@gmail.com

ORCID: 0000-0002-7514-6632

Date of receipt of the article: December 05, 2018 Article accepted for publication: February 21, 2019

\section{Чеський досвід підготовки майбутніх учителів до роботи в умовах інклюзивної освіти}

\section{Оксана Василівна Плужник}

аспірант кафедри педагогіки

ДВНЗ «Переяслав-Хмельницький державний педагогічний університет імені Григорія Сковороди»,

$\checkmark$ вул. Сухомлинського, 30, м. Переяслав-Хмельницький, Київська обл., Україна, 08401 


\section{Ольга Іллівна Шапран}

доктор педагогічних наук, професор, завідувач кафедри педагогіки

ДВНЗ «Переяслав-Хмельницький державний педагогічний університет імені Григорія Сковороди»,

вул. Сухомлинського, 30, м. Переяслав-Хмельницький, Київська обл., Україна, 08401

Дата надходження статті: 05 грудня 2018 p. Стаття прийнята до друку: 21 лютого 2019 р.

\section{Abstract}

The article examines the Czech experience of future elementary school teachers training for activities in the context of inclusive education. The main models of inclusive education in the world and specifically the Czech Republic are considered. The basic laws concerning the training of teachers, special teachers, assistants are analyzed. The basic teachers' competences are determined according to the Czech standard of the teacher's profession quality; the necessary conditions for conferring the qualification of primary and secondary school teachers are defined. The system of higher education in the Czech Republic and the educational programs of leading higher educational institutions for the preparation of primary school teachers and special teachers are considered. The Charles University and the Masaryk University were selected for the research as leading, because these institutions ranked the highest in world rankings. The article acquaints readers with the activity of pedagogical faculties of both universities. The particular attention was paid to the activities of the departments of pedagogy and special pedagogy. The curricula of training teachers, assistant teachers for a work in inclusive education were analyzed. This made it possible to state that bachelor/master's programs were designed to provide graduates with the necessary knowledge, ethical values and practical skills necessary for constructing a pedagogical career. The contents of the bachelor/master's program provides an extensive and deep knowledge in the fields of inclusive education, including the theory of special pedagogy, the necessary 
skills and abilities in providing medical services, knowledge of the behavior of a child with different pathologies or abnormalities. It is found that a theoretical training is given to most of the study time, the courses of in-depth specialization are offered. It is determined that in the process of special teachers' professional training in the Czech Republic, three main components can be distinguished: general pedagogical, special pedagogical, specialization with a choice in two main types of A and B. The bachelor training is carried out in two models: simultaneous (parallel, integrative) and sequential. During the study, it was emphasized that an adherence to the unified structure of training bachelors/masters of special education for all institutions of higher education in the Czech Republic contributes to improving their theoretical, methodological and practical basis, facilitates the students' transition from one educational institution to another, an admission to a magistracy in another institution of higher education, gives a few specializations. Consequently, the peculiarities and positive aspects of training specialists for a work in the conditions of inclusive education in the Czech Republic are highlighted in this article as those, that could be used in Ukraine taking into account the peculiarities and traditions of the national high school.

Key words: inclusive education, training of future primary school teachers, competencies, special education, training models, educational programs, specializations.

\section{References}

1. Agashev, D. V. \& Grankin, K. V. (2014). Problemyi ispolzovaniya $\mathrm{V}$ Rossii opyita razvitiya vyisshego yuridicheskogo obrazovaniya v gosudarstvah Evropeyskogo Soyuza (na primere Cheshskoy Respubliki) [Problems of using the European Union experience of developing higher legal education in Russia (on the example of the Czech Republic)]. Vestnik Tomskogo gos. un-ta. Pravo, 1 (11). Retrieved from http://cyberleninka.ru/ article/n/problemy-ispolzovaniya-v-rossii-opyta-razvitiyavysshego-yuridicheskogo-obrazovaniya-v-gosudarstvah-ev ropeyskogo-soyuza-na-primere [in Russian]. 
2. Antonenko, O. V. (2014). Pidhotovka vchyteliv inozemnykh mov u Cheskii respublitsi u svitli reformuvannia vyshchoi osvity Yevropy [Training of foreign languages teachers in the Czech Republic in the light of the European higher education reformation]. Pedahohichnyi almanakh, 24, 91-96 (in Ukrainian).

3. Bannyih, G. A. \& Tihomirova, A. M. (2014). Vyisshee obrazovanie v Chehii glazami prepodavateley UrGEU [Higher education in the Czech Republic in the eyes of the teachers of the UrGEU]. Upravlenets, 4/50/, 29-31 [in Russian].

4. Dolgaya, O. I. (2014). Obuchenie detey s osobyimi obrazovatelnyimi potrebnostyami v Cheshskoy Respublike [Teaching children with special educational needs in the Czech Republic]. Problemyi sovremennogo obrazovaniya, 1. [in Russian].

5. Inklyuzivnoe obrazovanie $\mathrm{v}$ shkolah Chehii, Belarusi, Slovakii i Avstrii [Inclusive education in schools of the Czech Republic, Belarus, Slovakia and Austria] 2018. 130 s. Retrieved from URL: AMOcz_Inkljuzivnoeobrazovanie-v-Chekhii-Slovakii-i-Avstrii.pd [in Russian].

6. Rubtsov V.V. \& Margolis A. A. Identifikatsiya profilya kompetentsiy i kvalifikatsii pedagoga [Identification of the teacher's profile of competencies and qualifications]. Cbornik portala psihologicheskih izdaniy PsyJournals.ru. Retrieved from http://psyjournals.ru/pj/2010-2/32221 [in Russian].

7. Shmidt, V. \& Panchoha, K. (2013). Modeli ligitimizatsii iklyuzivnogo obrazovaniya v Chehii [Models of litigation and inclusive education in the Czech Republic]. Zhurnal issledovaniy sotsialnoy politiki. Vol.11, 4, 547-560 [in Russian].

8. Bílá kniha. Národní program rozvoje vzdělávání v české republice. MŠMT ČR (2002). Retrieved from http://www.msmt.cz/dokumenty/bila-kniha-narodniprogram-rozvoje-vzdelavani-v-ceske-republice-formuje-vl adni-strategii-v-oblasti-vzdelavani-strategie-odrazicelospolecenske-zajmy-a-dava-konkretni-podnety-k-praciskol. 
9. Czech Prestige (2014). Retrieved from https://www.pragueacademy.ru/novosti/vsenovosti/item/227-pyaterka-cheskikh-vuzov-v-mirovom-rey tinge/227-pyaterka-cheskikh-vuzov-v-mirovom-reytinge.

10. Havel, J. \& Janík, T. (2004). (Eds.) Pedagogická praxe v pregraduální prípravě učitelì. Brno : PdF MU. ISBN 80210-3378-9.

11. Juklová, K. (2013). Začínající učitel z pohledu profesního vývoje. Vyd. 1., Univerzita Hradec Králové : Gaudeamus. 177 s. ISBN 978-80-7435-266-9.

12. Katedra speciální pedagogiky. Pedagogické fakulty Masarykovy university v Brně (2010). Retrieved from http:// www.ped.muni.cz/wsedu.

13. Masarykova univerzita (2018). Retrieved from http://www.muni.cz/.

14. Michalík, J.; Baslerová, P., Felcmanová, L. a kol. (2015). Katalog podpůrných opatření, Univerzita Palackého $v$ Olomouci. p. 19.

15. Mšmt ČR (2017). Retrieved from http://www.msmt.cz/ vzdelavani/ dalsi-vzdelavani/ ramcove-pozadavky-nastudijni-programy-jejichz-absolvovanim.

16. Univerzita Karlova (2018). Retrieved from http://cuni.cz.

17. Zákon č. 563/2004 Sb. O pedagogických pracovnících. MŠMT ČR (2016). Retrieved from http://www.msmt.cz/dokumenty-3/zakony.

\section{Вступ}

Сьогодні реформування української освіти є одним 3 основних питань державницької політики. Згідно Закону «Про освіту» (2017) в цьому році почалася активна модернізація початкової ланки освіти. Запропонована модель 12-річної школи внесла свої корективи не тільки в зміст освіти, але й у підготовку вчителів для початкової школи. Серед дев'яти основних змін Нової української школи стає напрямок створення належних умов для дітей з особливими освітніми потребами (ООП) для навчання спільно 3 однолітками. 
У сучасних умовах впровадження інклюзивної освіти в Україні цікавим виявляється досвід європейських країн, таких як Чехія, у підготовці вчителів /асистентів учителів до роботи в школі. Вивчення чеського досвіду підготовки майбутніх учителів початкових класів до діяльності в умовах інклюзивної освіти становить великий інтерес для аналізу, осмислення й збагачення сучасної науки та оптимізації вітчизняної спеціальної освіти. Система педагогічної освіти Чехії будується на принципах інноваційності та людиноцентризму. Вона спрямована на підготовку кваліфікованого вчителя, який має відповідати широкому спектру вимог, що містять знання, вміння і компетенції, професійні цінності та практичний досвід (Антоненко, 2014: 91-96).

Учитель у сучасній чеській школі - це модератор навчального процесу, а не просто лектор. Основний персонаж у школі - учень. Учителі - партнери учнів. Вони співпрацюють для досягнення спільної мети. Провідною ідеєю організаційної моделі педагогічної освіти в Чеській Республіці є забезпечення професійної підготовки вчителя на всіх етапах педагогічного становлення. Такий підхід $\epsilon$ наслідком послідовного і чіткого плану реформи педагогічної освіти, яка почалася у 2001 році, коли уряд Чеської Республіки затвердив «Національну програму розвитку освіти й виховання в Чеській Республіці». Цей документ був опублікований під назвою «Біла книга» (Bílá kniha, 2002). Основним положенням Білої книги стала розробка та затвердження професійних стандартів для всіх категорій вчителів. Найновіший професійний стандарт педагогічної освіти Чехії визначений у проекті «Кар'єрна система» (JUKLOVÁ, 2013).

Розробка нових компетенцій вчителя в Чехії здійснена на основі визначення ключових завдань школи, цілей навчання учнів: навчання знання; навчання спільного життя з іншими; навчання діï; навчання життєдіяльності. До основних компетенцій вчителя, закріпленим в професійному стандарті, віднесено: компетенція у шкільному предметі, компетенція у дидактиці і психодидактиці, компетенція у 
педагогіці, компетенція у діагностиці. Виділені також соціальні, психосоціальні, комунікативні, управлінські, професійні та особистісні компетенції. Важливим є те, що на державному рівні поняття якості підготовки вчителя і професійний стандарт задано у загальному вигляді.

Отже, вивчення досвіду якісної підготовки майбутніх учителів до професійної діяльності в умовах інклюзивної освіти обумовлено потребою реформування освіти України та пошуку нових перспективних ідей, методів, технологій удосконалення освітнього процесу 3 урахуванням європейських реалій.

Дослідженням євроінтеграційних процесів, реформування освіти, підготовки педагогічних кадрів у системі інклюзивної освіти Чехії займаються такі вітчизняні та зарубіжні науковці як О. Антоненко, Г. Банних, О. Долгая, К. Панчоха, В. Рубцов, А. Марголіс, А. Тихомирова, I. Трунда, В. Шмідт та інші.

Вивчення різних наукових джерел доводить, що у процесі становлення й розвитку педагогічної освіти в Чехії відбулася трансформація мети підготовки майбутніх учителів: від забезпечення суспільства професійними вчителями на першому етапі до підготовки полікультурних учителів на сучасному етапі. Зі зміною погляду на освіту учнів з особливими освітніми потребами (ООП) у напрямку інклюзивної освіти переглядається і статус учителів та спеціальних педагогів у школах. Відповідно зазнає змін і концепція підготовки таких учителів, що $є$ недостатньо дослідженою.

Мета написання статті: 3'ясувати особливості та переваги чеського досвіду підготовки майбутніх учителів початкових класів до діяльності в умовах інклюзивної освіти для можливості його використання в Україні з урахуванням особливостей і традицій вітчизняної вищої школи.

\section{Матеріал і методи досліджень}

Для досягнення поставленої мети та вирішення завдань дослідження використано сукупність взаємопов'язаних методів. Для збору матеріалу застосовувалися загальнонаукові методи: метод вивчення наукових джерел 
(педагогічно-методичної літератури та нормативнозаконодавчих актів Чехії); аналіз, синтез, порівняння та узагальнення - для з’ясування особливостей концептуальних підходів, покладених в основу освітніх послуг у Чехії. Для аналізу організації професійної підготовки майбутніх учителів початкової школи застосовано такий комплекс наукових методів: метод опису із прийомами порівняння, синтезу й узагальнення теоретичної інформації; метод порівняльного аналізу зібраного матеріалу; метод статистики (для кількісного зіставлення особливостей дисциплінарного навантаження на спеціальності вчителя початкової школи 3 метою виявлення їх якісних характеристик); метод компаративного аналізу, що дозволив порівняти сучасний стан підготовки вчителів початкових класів до роботи в умовах інклюзивної освіти в Україні та Чехії; наукової екстраполяції, використаний для окреслення можливостей використання чеського досвіду в аспекті досліджуваної проблеми в Україні. В ході дослідження використовувалися спеціальні лінгвістичні методи редагування і перекладу інформації з чеської та англійської мов.

\section{Результати та їх обговорення}

Відповідно до існуючих у XXI столітті демократичних і гуманістичних тенденцій у світі реалізується принцип інтегрованого підходу, що надає дітям з проблемами в розвитку можливості навчатися в масовій школі разом зі звичайними дітьми. О. Долгая відмічає, що при цьому склалися три основні моделі інклюзивної освіти:

- модель «одного шляху» - інтеграція всіх дітей в рамках масової школи (Греція, Іспанія, Італія, Португалія, Швеція, Норвегія і Кіпр);

- модель «двох шляхів» - наявність двох самостійних систем освіти, які існують на основі спеціальних законів, обов'язкових для масової і спеціальної освіти (Бельгія, Нідерланди, Болгарія, Румунія, Латвія);

- модель «багатьох шляхів» - існує безліч концепцій, які об'єднують елементи масової та спеціальної освіти (Австрія, Великобританія, Угорщина, Данія, Німеччина, Литва, Люксембург, Ісландія, Ірландія, Польщза, Француія, 
Словаччина, Словенія, Фінляндія, Чехія та інші країни) (Долгая, 2014: 99).

Чехія належить до моделі «багатьох шляхів», підтримує політику Європейського Союзу, тому тенденції у вищій освіті щодо підготовки педагогічних кадрів обумовлені Болонською декларацією. Так, Законом Чехії від 24 вересня 2004 р. «Про педагогічних працівників» (Zákon o pedagogických pracovnících, 2016) визначено, що ступінь магістра необхідна умова для присвоєння кваліфікації вчителів початкової та середньої школи. У частині 2 цього Закону щодо отримання професійної кваліфікації педагогічними працівниками зазначається, що:

§ 7 Учитель початкових класів у школі, яка здійснює освітні заходи для дітей з ООП, отримує професійну кваліфікацію, здобувши вищу освіту за акредитованою магістерською програмою в галузі педагогічних наук, що орієнтована на спеціальну освіту для вчителів.

$\S 18$ Спеціальний педагог отримує професійну кваліфікацію, здобувши вищу освіту за акредитованою магістерською програмою в галузі педагогічних наук, що орієнтована на спеціальну педагогіку, різні галузі спеціальної педагогіки $i$ додаткові дослідження для розширення професійної кваліфікації, які пропонуються університетом.

$\S 20$ Асистент учителя, який здійснює безпосередню педагогічну діяльність в класі, де навчаються діти з ООП або в школі, що забезпечує виховання дітей у сфері інклюзії, отримує професійну кваліфікацію, здобувши: або вищу освіту, або вищу професійну освіту, або середню освіту за відповідними акредитованими освітніми програмами у сфері освіти 3 педагогічною спрямованістю чи в результаті вивчення іншої акредитованої навчальної програми (програма вивчення педагогіки, програма навчання протягом усього життя, програма навчання асистентів учителя, що здійснюється середніми школами, орієнтованими на педагогіку). Отже, у чеських школах у роботі з дітьми з ООП допомагає асистент. Це може бути не тільки людина з вищою педагогічною освітою, але й вищою професійною й середньою освітою, яка прослухала спеціальний курс 
тривалістю в 80 годин і отримала право супроводжувати дітей з різними порушеннями на уроках. В Україні асистентів педагогів недостатньо i, як правило, вони повинні мати тільки вищу або вищу професійну освіту.

Учителі початкових та середніх шкіл готуються в Чеській Республіці дев'ятьма педагогічними факультетами. Крім того, багато вчителів (особливо для середніх шкіл) випускники філософських чи природничих факультетів. 3 початку 1990-х рр. педагогічні факультети розширюють можливості підготовки вчителів до роботи з різноманітною групою учнів. У Чеській Республіці існує досить широкий спектр додаткових курсів та програм, які організовуються освітніми центрами університетів, а також приватними акредитованими навчальними закладами. Одним із варіантів також є додаткове навчання спеціальної педагогіки, яку пропонують деякі факультети освіти починаючи з 2014 р. (Michalík, Baslerová, Felcmanová, 2015: 19).

Система вищої освіти Чехії налічує понад 80 закладів, 3 яких близько 30 є державними (суспільно-державними), решта - приватні. Суспільно-державними закладами вищої освіти називаються самоврядні навчальні заклади, створені державою або за іiї участі (в тому числі на базі державного майна), які здійснюють навчання студентів на підставі державних замовлень за рахунок бюджетних коштів i володіють значною автономією відносно Міністерства у справах молоді, спорту і освіти (MŠMT). Крім цього, в Чехії діють чисельні філії зарубіжних вишів, дипломи яких, однак, підлягають обов'язковій нострифікації через будь-яку державну (суспільно-державну) вищу освітню установу Чеської Республіки, яка має змістовно схожу або аналогічну акредитовану освітню програму (Агашев, Гранкин, 2014).

На даний час у Чехії існує близько 100 факультетів, на яких можна здобути не менше 4000 різних спеціальностей (у цей список не враховано художні школи i духовні семінарії). Діяльність закладів вищої освіти регулює Закон про Вищу освіту №. 111/1998 Sb. (1998).

3 урахуванням рейтингу університетів QS World University Rankings серед чеських університетів найвищу 
позицію щодо підготовки педагогічних кадрів займає Карлів університет та Університет Масарика (Czech Prestige, 2014). Карлів університет - це найпрестижніший вищий учбовий заклад в Чехії та найстаріший університет Центральної Свропи, який заснований у 1348 р. Чеським королем та Римським імператором Карлом IV у Празі. Карлів університет входить до Асоціації європейських закладів вищої освіти разом із такими університетами як Оксфордський, Лейденський, Бонський, університетами Болоньї та Женеви. У цьому університеті навчання триває від 3 до 7 років в залежності від обраної спеціальності. В університеті навчаються студенти з 48 країн світу, значну частку з них становлять студенти з Америки, Великобританії та Австрії. Цьому сприяє високий міжнародний авторитет, міжнародне визнання дипломів та якість підготовки спеціалістів. Велика увага приділяється міжнародному співробітництву 3 престижними освітніми та науковими закладами. Карлів університет має договори про міжнародне співробітництво з 190 зарубіжними університетами (Univerzita Karlova, 2018).

Освітній процес на педагогічному факультеті цього університету, який заснований у 1946 році, відрізняються демократизмом і свободою вибору предметів для навчання. Так, навчальні плани підготовки бакалаврів на факультеті дуже ліберальні, вони включають в себе обов'язкові курси (яких небагато, але за них студент отримує більшу частину iз необхідних 130 кредитів за семестр) і кілька курсів за вибором. На курс за вибором має записатися не менше трьох студентів, якщо ж протягом трьох семестрів цей курс ніхто не обирає, то його видаляють 3 навчального плану. Стандартний бакалаврат - 4 роки, максимальний термін навчання на бакалавраті - 6 років (2 останні роки навчання студент проплачує, держава гарантує безкоштовне навчання тільки протягом 4 років). Якщо і за цей час студент не засвоює програму, то його відраховують без диплома. На гуманітарний факультет студенти вступають на єдину загальну бакалаврську програму гуманітарної освіти. Після закінчення бакалаврату вони вибирають різні напрямки для 
магістратури та отримують різні дипломи - філософів, істориків, антропологів та ін. Заочного навчання немає, тільки очне і комбіноване. Останнє передбачає читання курсів для студентів у вихідні дні у стінах університету, там же складаються заліки та іспити. На перший курс гуманітарного факультету зараховують близько 600 чоловік, а закінчує його тільки 200. Це пов'язано зі значним обсягом різноманітної самостійної роботи, з якою далеко не всі студенти можуть упоратися (Банных, Тихомирова, 2014: 29-31).

У Карловому університеті створені всі умови для навчання студентів з ООП. У цьому закладі вищої освіти для людей з інвалідністю передбачено безбар'єрне середовище, на яке виділяються значні бюджетні кошти. Також на базі університету організований офіс для молоді з особливими освітніми потребами. Однак, Карлів університет відчуває нестачу кваліфікованих кадрів, які б змогли працювати 3 «особливими» студентами.

Університет Масарика - другий за величиною державний університет Чехії, розташований у м. Брно. Університет $є$ одним з найважливіших освітніх та наукових закладів у Чеській Республіці та знаним в Центральній Європі університетом з сильним демократичним духом 3 моменту його заснування у 1919 р. Університет Масарика був у числі перших університетів, які запровадили трирівневу структуру освіти (бакалавр - магістр - доктор), а в 2010 р. єдиний в Чехії виграв European Credit Transfer System Label (ECTS Label). Цей сертифікат, виданий Європейською комісією, підтверджує якість вищої школи та декларує, що заклад оцінюється за кредитною системою. Навчання в університеті проходиться чеською мовою, проте для тих, хто добре володіє англійською мовою, $\epsilon$ великий вибір навчальних програм на англійській мові (Masarykova univerzita, 2018).

Педагогічний факультет університету був заснований восени 1946 року як п'ятий факультет університету Масарика. Факультет активно сприяе прийняттю «європейських поглядів» у сфері вищої освіти, збагачує зміст 
навчальних програм. Основним завданням педагогічного факультету є підготовка та перепідготовка вчителів для першої та другої ланки початкової школи. Крім загальної педагогіки, вивчають також спеціальну і соціальну педагогіку. Факультет забезпечує отримання ступеня бакалавра, магістра, продовженого магістра та докторів. Також діють програми навчання протягом усього життя, які забезпечують курси спеціалізації, перепідготовки, короткострокові курси та відповідають вимогам сучасної освіти.

Кафедра педагогіки належить до провідних кафедр педагогічного факультету Університету Масарика. Ця кафедра бере активну участь у професійній підготовці студентів щодо отримання кваліфікацій «спеціальний педагог», «вихователь», «асистент учителя».

Кафедра спеціальної освіти педагогічного факультету університету Масарика, що заснована у 1994 р., спрямована на підготовку майбутніх вчителів та спеціальних педагогів 3 урахуванням поточних соціальних потреб для поступової реалізації інтеграції дітей / учнів з особливими освітніми потребами у звичайні школи (Katedra speciální pedagogiky, 2010). Сучасні спеціальні навчальні програми з педагогіки розроблені з урахуванням глобальних тенденцій у вихованні дітей /учнів з ООП. У даний час кафедра спеціальної освіти пропонує 16 акредитованих навчальних курсів бакалаврату, магістратури, аспірантури та докторантури у чистому та комбінованому вигляді на чеській, англійській та німецькій мовах.

Цікавим i результативним $є$ досвід Університету ім. Масарика у впровадженні активного репетиторства. Суть його в тому, що репетиторами обов'язково стають студенти під час проходження педагогічної практики. Практика проходить не лише в закладах освіти, а й у сім'ях, де є діти 3 ООП. Деякі студенти займаються активним репетиторством упродовж усього терміну навчання у вищій школі.

В університетах Чехії зустрічаються дві моделі підготовки бакалаврів: одночасна (паралельна, інтегративна) i послідовна. В одночасній моделі підготовки 
предмети загальних дисциплін вивчаються паралельно із обраними педагогічними, психологічними та дидактичними дисциплінами. У послідовній моделі на першому етапі підготовки вивчаються загальні дисципліни і лише потім спеціальні професійні дослідження (HAVEL, JANÍK, 2004). Перевага паралельної моделі у тому, що педагогікопсихологічна, дидактична, а також практична підготовка є взаємопов'язаними та сприяють більш інтегрованій професійній підготовці. 3 іншого боку, послідовна модель може бути більш доцільною, оскільки педагогічна та дидактична підготовка є більш концентрованими, а практика не розкидана на короткі періоди часу, а довша і більш систематизована.

На інституційному рівні, тобто в конкретному університеті, професійний стандарт освіти конкретизується на детальному рівні для окремих категорій учителів у формі переліку компетенцій, а також усіх складових програми навчання. Така деталізована форма стандарту отримала назву «Профіль випускника». Розроблена на цій основі загальна схема організації підготовки вчителя визначає основні складові педагогічної освіти. Так, на вивчення дидактики шкільного предмета відводиться в середньому до $55 \%$ всієї програми, на психолого-педагогічний блок - 35\%, на загально-університетські дисципліни - 10\%, на практику викладання з психолого-педагогічною складовою - 10-15\% (Рубцов, Марголис, 2010). Співвідношення основних компонентів навчального плану наступні: загальні дисципліни × педагогічна пропедевтика (педагогікопсихологічна пропедевтика) $\times$ дидактика $\times$ практика $\times$ підсумкова дипломна робота.

У процесі професійної підготовки спеціальних педагогів у Чехії можна виділити три основні складові:

- загальна педагогічна (педагогіка, психологія, методологія, соціологія для спеціальних педагогів, соціальна патологія);

- спеціальна педагогічна (інтегративна (спеціальна) педагогіка, інклюзивна освіта, спеціальна педагогічна діагностика, патопсихологія та психопатологія, нейропсихологія та медична пропедевтика); 
- спеціалізації з вибором у двох основних типах $A$ i $B$ (таблиця 1)

\section{Вибір спеціалізації за типами А і B}

\begin{tabular}{|c|c|}
\hline \multicolumn{2}{|r|}{ Tй A } \\
\hline 1-а спеціалізація & догопедія \\
\hline 2-а спеціалізація & сурдопе:гія \\
\hline 3-я спеціалізадія & конкретні проб̆лемп навчання \\
\hline 4-а спеціалізащія & поглиблене вивчення логопедії та сурдопедії I.. II. \\
\hline \multicolumn{2}{|r|}{ Tип B } \\
\hline 1-а спеціалізація & пспхопедія \\
\hline 2-а спеціалізація & 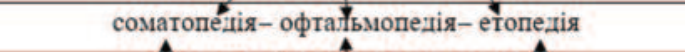 \\
\hline 3-я спеціатізація & конкретні проблемп навчання \\
\hline 4-а спеціалізашія & 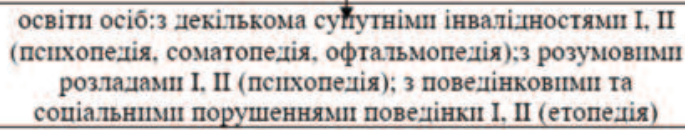 \\
\hline
\end{tabular}

\section{Таблиия 1. Вибір спеиіалізащії}

Перша i друга спеціалізації реалізуються на бакалаврському рівні, третя і четверта - на магістерському рівні. Друга спеціалізація залежить від того, чи це дворівневе або однорівневе навчання. У випадку дворівневого навчання, друга спеціалізація починається у магістратурі. Всі спеціалізації доповнюються великим вибором факультативних предметів і супроводжуються практикою у відповідних школах та установах.

Вивчення програми спеціальної освіти фокусується не лише на вивченні спеціальної педагогіки, але й засвоєнні таких предметів як: логопедія і сурдопедія; навчання дітей $з$ множинними порушеннями (психопедія, соматопедія, офтальмопедія); $з$ розумовими вадами (психопедія); 3 поведінковими розладами (етопедія); $з$ мовними порушеннями (логопедія, сурдопедія); специфічними порушеннями навчання (Katedra speciální pedagogiky, 2010).

Стандартна загальна кількість кредитів для навчання в програмі бакалавра (Вс.) становить 180 кредитів, 3 подальшим продовженням магістерської програми (NMgr.) ще 120 кредитів і 300 кредитів у програмі магістра (Mgr.).

(C) Ольга Іллівна Шапран 
Бакалаврська програма спеціальної педагогіки повинна забезпечувати міцний фундамент зі спеціальних навчальних дисциплін без спеціалізацій, для того, щоб їх випускники могли продовжувати навчання у будь-якій магістерській програмі спеціальної педагогіки. Самостійна бакалаврська програма спеціальної педагогіки не дає кваліфікацію педагогічного працівника. Але у поєднанні з нею можна отримати кваліфікацію вчителя у класі чи школі, створеній для дітей або учнів з ООП.

Випускник магістерської програми спеціальної педагогіки (будь-якої спеціалізації) набуває професійної кваліфікації спеціального педагога, а також експерта 3 надання консультаційної допомоги в школі чи консультаційному центрі. Після навчання за магістерською програмою спеціальної педагогіки можна також отримати кваліфікацію вчителя початкової школи. Програма спеціальної педагогіки (особливо логопедіï) може бути акредитована як неструктуроване п'ятирічне магістерське дослідження.

Отже, підготовка вчителів та асистентів вчителів Чехії для роботи в школі в умовах інклюзивної освіти здійснюється в провідних університетах за різними програмами. Однак, держава приділяє багато уваги i просвітницькій роботі та підтримує громадські організації, які працюють у цьому напрямку. Так, у країні започатковано цикли освітніх семінарів, наприклад, для працівників педагогічних консультацій; серію інтенсивних освітніх семінарів для вчителів, які проводяться спеціально навченими, так званими «імплементаторами» або тренерами. Державою активно підтримується об'єднання Rytmus, яке займається навчанням і підбором асистентів для установ освіти, контролює, чи всі підприємства виконують завдання 3 працевлаштування «особливих» людей; фонд KontoBariery, що збирає кошти на реалізацію проектів інклюзивної освіти; асоціація Ту а Ја як своєрідний клуб для людей 3 інвалідністю; майстерня 3 соціальної терапії Exodus, відвідувачі якої виготовляють вироби і реалізовують їх на ярмарках тощо. Таким чином, створюється цілісна система підготовки фахівців до роботи в умовах інклюзивної освіти. 
У підсумку хотілось би зупинитися на сучасних моделях легітимізації інклюзивної освіти. В. Шмідт та К. Панчоха виділяють три моделі легітимізації інклюзивної освіти в Чехії: output-легітимізацію, визнає владу як ту, що ефективно забезпечує очікування громадян; inputлегітимізацію, засновану на прямій участі громадян; throughput-легітимізацію, яка забезпечує прозорість процедур прийняття рішень і взаємну відповідальність. Автори відзначають, що в Чехії існує монополія outputлегітимізації, що блокує системне розуміння напрямків реформ в умовах інклюзивної освіти. В. Шмідт та К. Панчоха доводять, що в Чехії надмірне значення відводиться методиці навчання, але ігнорується, наприклад, роль самоорганізації батьків, використання процедур оцінки розвитку дитини, планування комплексної програми підтримки дитини і ii оточення тощо. Отже, ці вчені окрім позитивних сторін впровадження інклюзії в Чехії виділяють i напрямки подальшої роботи з дітьми з особливими потребами (Шмидт, Панчоха, 2013: 557).

Споріднену думку до наукових позицій В. Шмідта i К. Панчохи висловлює дослідник в галузі інклюзивної освіти, директор базової школи Вратіславова Чеської Республіки I. Трунда. Він зазначає, що «інклюзія ні в якому разі не може визначатися як обмежений перелік елементів або методів, це шлях безперервної педагогічної діагностики та проектування освітньої стратегії - як на рівні класу, так і груп і окремих осіб» (Инклюзивное образование в школах Чехии, Беларуси, Словакии и Австрии: практический опыт, 2018: 26). Отже, досвід упровадження інклюзивної освіти у Чеській Республіці доводить необхідність якісної підготовки майбутніх фахівців до роботи в умовах інклюзії та постійне їх самовдосконалення.

\section{Висновки}

Аналіз навчальних програм закладів вищої освіти Чехії, що здійснюють підготовку вчителів, асистентів учителів до роботи з дітьми, що мають ООП, дає змогу стверджувати, що програми підготовки бакалаврів / магістрів розроблені таким чином, щоб забезпечити випускників необхідними знаннями, 
етичними цінностями та практичними навичками, необхідними для побудови педагогічної кар'єри. Зміст підготовки бакалаврів / магістрів забезпечує широкі й глибокі знання у галузях, що стосуються інклюзивної освіти, включаючи теорію спеціальної педагогіки, необхідні вміння та навички з надання медичних послуг, знання поведінки дитини з різними патологіями чи відхиленнями. Теоретичній підготовці відводиться більша частина навчального часу, пропонуються курси поглибленої спеціалізації.

Дотримання єдиної структури підготовки бакалаврів / магістрів спеціальної освіти усіма закладами вищої освіти Чехії сприяє покращенню їх теоретичної, методичної й практичної бази, спрощує перехід студентів 3 одного навчального закладу до іншого, вступ до магістратури в іншому закладі вищої освіти, дає змогу отримати декілька спеціалізацій. Окрім якісного засвоєння ряду дисциплін у вищій школі та певних методів та технологій спеціальної педагогіки, важливим залишається просвітництво, робота громадських організацій, батьків, розробка та впровадження комплексних програм підтримки дитини і іï оточення.

Позитивний чеський досвід підготовки майбутніх учителів початкових класів до діяльності в умовах інклюзивної освіти може бути використаний в Україні 3 урахуванням особливостей і традицій вітчизняної вищої школи. Це дозволить оптимізувати систему підготовки таких фахівців і в цілому сприятиме полегшенню впровадження інклюзивної освіти в Україні.

\section{Література}

1. Агашев Д. В., Гранкин К. В. Проблемы использования в России опыта развития высшего юридического образования в государствах Европейского Союза (на примере Чешской Республики). Вестник Томского гос. ун-та. Право. 2014. №1 (11). URL: http:/cyberleninka.ru/article/n/problemy-ispolzovaniya-vrossii-opyta-razvitiya-vysshego-yuridicheskogo-obrazovan iya-v-gosudarstvah-evropeyskogo-soyuza-na-primere (дата обращения: 07.11.2017). 
2. Антоненко О. В. Підготовка вчителів іноземних мов у Чеській республіці у світлі реформування вищої освіти Європи. Педагогічний альманах. 2014. Випуск 24. C. 91-96.

3. Банных Г. А., Тихомирова А. М. Высшее образование в Чехии глазами преподавателей УрГЭУ. Управленец. 2014. № 4/50/. c. 29-31.

4. Долгая О. И. Обучение детей с особыми образовательными потребностями в Чешской Республике. Проблемы современного образования. 2014. № 1 .

5. Инклюзивное образование в школах Чехии, Беларуси, Словакии и Австрии: практический опыт. 2018. 130 с. URL: AMOcz_Inkljuzivnoe-obrazovanie-v-ChekhiiSlovakii-i-Avstrii.pd.

6. Рубцов В. В., Марголис А. А. Идентификация профиля компетенций и квалификации педагога. Сборник портала психологических изданий PsyJournals.ru. 2010. № 2. URL: http://psyjournals.ru/pj/2010-2/32221.shtml (дата обращения: 20.09.2017).

7. Шмидт В., Панчоха К. Модели лигитимизации иклюзивного образования в Чехии. Журнал исследований сощчиальной политики. 2013. Т. 11. № 4. C. 547-560.

8. Bílá kniha. Národní program rozvoje vzdělávání v české republice. MŠMT ČR. 2002. URL: http://www.msmt.cz/ dokumenty/ bila-kniha-narodni- program-rozvojevzdelavani-v-ceske-republice-formuje-vladni-strategii-v-ob lasti-vzdelavani-strategie-odrazi-celospolecenske-zajmy-adava-konkretni-podnety-k-praci-skol.

9. Czech Prestige. 2014. URL: https:// www.pragueacademy.ru/ novosti/vse-novosti/item/227pyaterka-cheskikh-vuzov-v-mirovom-reytinge/227-pyaterk a-cheskikh-vuzov-v-mirovom-reytinge.

10. Havel J.; Janík, T. (Eds.) Pedagogická praxe v pregraduální připravě učitelů. Brno : PdF MU, 2004. ISBN 80-210-3378-9. 
11. Juklová K. Začínající učitel z pohledu profesního vývoje. Vyd. 1., Univerzita Hradec Králové : Gaudeamus. 2013. 177 s. ISBN 978-80-7435-266-9.

12. Katedra speciální pedagogiky. Pedagogické fakulty Masarykovy university v Brně. 2010. URL: www.ped.muni.cz/wsedu.

13. Masarykova univerzita. 2018. Retrieved from URL: //www.muni.cz/.

14. Michalík J.; Baslerová, P., Felcmanová, L. a kol., Katalog podpuirných opatření, Univerzita Palackého v Olomouci. 2015. p. 19.

15. MŠMT ČR. 2017. URL: http://www.msmt.cz/ vzdelavani/dalsi-vzdelavani/ramcove-pozadavky-nastudijni-programy-jejichz-absolvovanim.

16. Univerzita Karlova. 2018. URL: http://cuni.cz.

17. Zákon č. 563/2004 Sb. O pedagogických pracovnících. MŠMT C̆R. 2016. URL://www.msmt.cz/dokumenty3/zakony.

\section{Плужник О.В., Шапран O.I.}

\section{Чеський досвід підготовки майбутніх учителів до роботи в умовах інклюзивної освіти}

\section{Анотація}

У статті досліджено чеський досвід підготовки майбутніх учителів початкової школи до діяльності в умовах інклюзивної освіти. Проведено огляд основних законів, що стосуються підготовки вчителів, спеціальних учителів, асистентів. Визначено основні компетенції вчителів відповідно до чеського стандарту якості професії вчителя та необхідні умови для присвоєння кваліфікації вчителів початкової та середньої школи. Розглянуто систему вищої освіти в Чеській Республіці та освітні програми провідних вищих навчальних закладів 3 підготовки вчителів початкових класів та спеціальних педагогів. Визначено особливості та позитивні аспекти підготовки фахівців для роботи в умовах 
інклюзивної освіти в Чехії, які можуть бути використані в Україні 3 урахуванням особливостей та традицій національної вищої школи.

Ключові слова: інклюзивна освіта, підготовка майбутніх учителів початкових класів, компетенції, спеціальна освіта, моделі підготовки, освітні програми, спеціалізації.

\section{Плужник О.В., Шапран О.И.}

Чешский опыт подготовки будущих учителей к работе в условиях инклюзивного образования

\section{Аннотация}

В статье исследовано чешский опыт подготовки будущих учителей начальных классов к деятельности в условиях инклюзивного образования. Проведен обзор основных законов, касающихся подготовки учителей, специальных учителей, ассистентов. Определены основные компетенции учителей согласно чешского стандарта качества профессии учителя. Рассмотрена система высшего образования Чехии и образовательные программы ведущих высших учебных заведений по подготовке учителей начальной школы и по специальной педагогики. Определены особенности и положительные стороны подготовки специалистов к работе в условиях инклюзивного образования, перспективные направления работы, которые могут быть использованы в Украине с учетом особенностей и традиций отечественной высшей школы.

Ключевые слова: инклюзивное образование, подготовка будущих учителей начальных классов, компетенции, специальное образование, модели подготовки, образовательные программы, специализации. 